\title{
A case of unilateral optic disc swelling with chronic active Epstein-Barr virus infection
}

This article was published in the following Dove Press journal:

Clinical Ophthalmology

28 August 2010

Number of times this article has been viewed

\author{
Naoko Aizawa' \\ Toru Nakazawa' \\ Masahiko Shimura ${ }^{2}$ \\ 'Department of Ophthalmology, \\ Tohoku University Graduate School \\ of Medicine, Sendai, Miyagi, Japan; \\ ${ }^{2}$ Department of Ophthalmology, NTT \\ East Japan Tohoku Hospital, Sendai, \\ Miyagi, Japan
}

\begin{abstract}
Ocular complications of chronic active Epstein-Barr virus (EBV) infection have rarely been reported and are usually associated with systemic symptoms. We described a 17-year-old boy with unilateral optic disc swelling without any systemic symptoms at the initial onset. Antibody titers to EBV were markedly elevated. Treatment with immunosuppressants and corticosteroids dramatically relieved all his symptoms, including unilateral optic swelling and visual field abnormalities.
\end{abstract}

Keywords: Epstein-Barr virus, optic disk swelling

\section{Introduction}

Chronic active Epstein-Barr virus (EBV) infection (CAEBV) syndrome belongs to a category of EBV-related disease. Ocular complications of CAEBV have rarely been reported and are usually associated with systemic symptoms, including chronic fatigue, low-grade fever, pharyngitis, dark urine, and malaise, that are usually observed prior to visual disturbances. ${ }^{1}$

We describe a rare case of unilateral optic disc swelling without any systemic symptoms at the initial onset. It was not diagnosed as CAEBV until EBV-specific immunological studies were done. Unilateral optic disc swelling was initial and unique signs of CAEBV in this case.

\section{Case report}

A healthy, 17-year-old boy was diagnosed with visual field abnormalities in his left eye and referred to our outpatient clinic for unilateral optic disc swelling. He had no history of chronic fatigue, recurrent fever, or other systemic symptoms. At his initial visit, best-corrected visual acuity (BCVA) in his left eye was 20/20. Fundus examination revealed prominent optic disc swelling and tortuous vessels (Figure 1A). Visual field abnormalities with enlargement of Marriott's scotoma (Figure 1B) and an afferent pupillary defect were observed in his left eye. However, there were no ocular inflammatory symptoms. Magnetic resonance image results showed no intracranial abnormalities. At that time, his blood tests revealed no abnormalities (white blood cell count: 4,900/ $\mu \mathrm{L}$, red blood cell count: $4.65 \times 10^{6} / \mu \mathrm{L}$, platelet count: $141 \times 10^{3} / \mu \mathrm{L}$, hemoglobin level: $13.2 \mathrm{~g} / \mathrm{dL}$, glutamic-oxaloacetic transaminase level: $36 \mathrm{IU} / \mathrm{L}$, glutamic-pyruvic transaminase level: $44 \mathrm{IU} / \mathrm{L}$, blood urea nitrogen level: $12 \mathrm{~g} / \mathrm{dL}$, creatinine level: $0.8 \mathrm{mg} / \mathrm{dL}$, total cholesterol level: $110 \mathrm{mg} / \mathrm{dL}$, sodium level: $140 \mathrm{mEq} / \mathrm{L}$, and potassium level: $3.9 \mathrm{mEq} / \mathrm{L}$ ). 
A

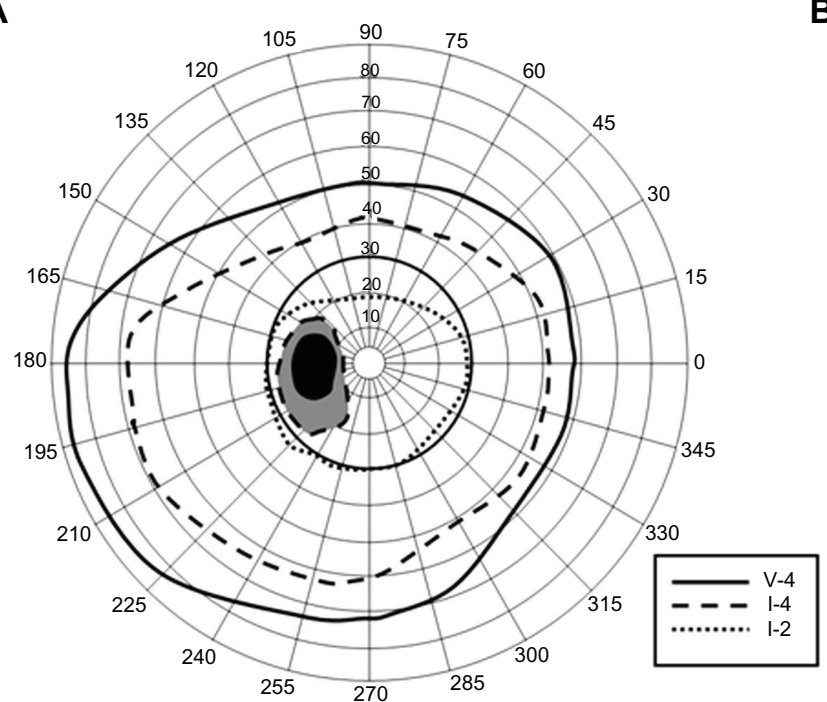

B

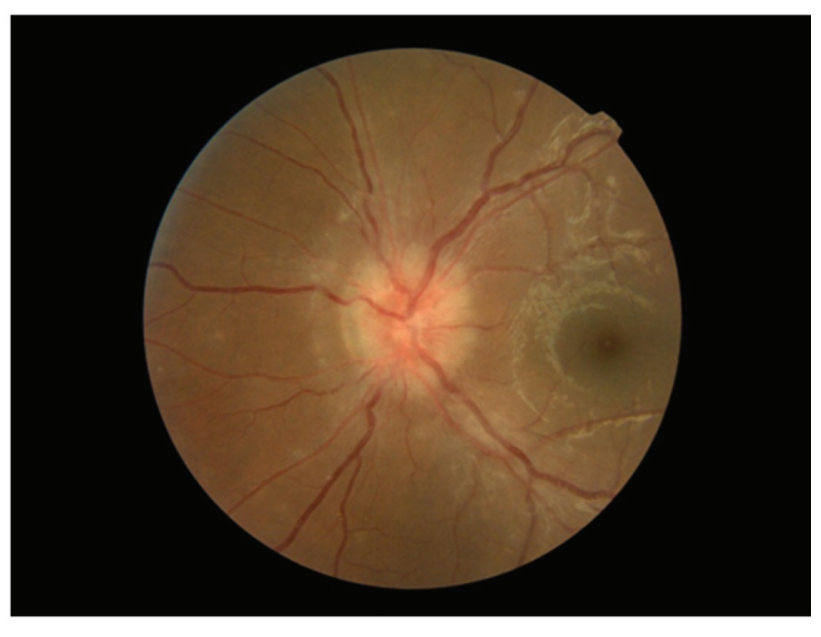

Figure I At the initial visit, A) visual field by Goldmann perimeter indicated enlargement of Mariott's scotoma. B) Fundus photograph of the left eye showed the reddish, swollen optic disc.

Two weeks after the onset of his ocular symptoms, acute iridocyclitis and retinal vasculitis were observed in association with a slight fever. His left BCVA was decreased to 20/40. Specific viral immunological studies revealed elevated levels of anti-EBV antibody (viral capsid antigen [VCA]immunoglobulin [Ig]G: 10,240, VCA-IgA: 1,280, VCA-IgM: $<10$, early antigen [EA]-IgG: 2,560, and EA-IgA: 80; note that each titer $<10$ is normal) and low titers of Epstein-Barr nuclear antigen (EBNA: 40). DNA of EBV: 1,834 copy/0.2- $\mu \mathrm{g}$ DNA (B cells: 33 copy/100-ng DNA, T cells: 75 copy/100-ng DNA, and natural killer [NK] cells: 1,100 copy/100-ng DNA).
Elevated levels of EBVT cells and NK cells along with clinical symptoms of EBV infection indicated CAEBV.

Immediately after the diagnosis, the patient received systemic administration of immunosuppressants and corticosteroids. Three months after chemotherapy, ocular inflammation and optic disc swelling gradually regressed, and his BCVA returned to 20/20. As depicted in Figure 2, visual field abnormalities were also improved. Levels of anti-EBV antibody were decreased (VCA-IgG: 1,280, VCA-IgA: 80, EA-IgG: 160, and EA-IgA: 10) with low antibody titers of EBNA: 40.
A

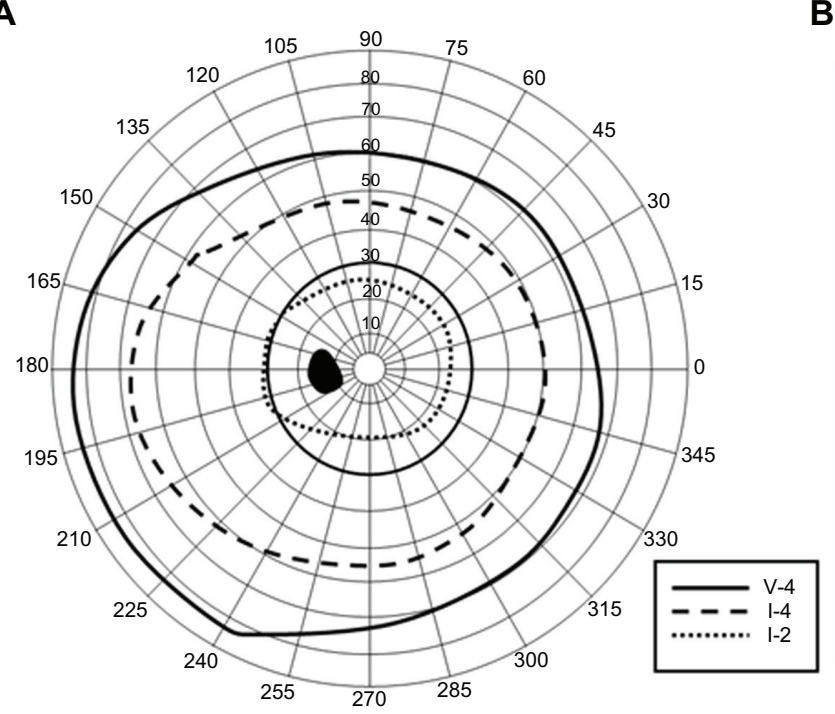

B

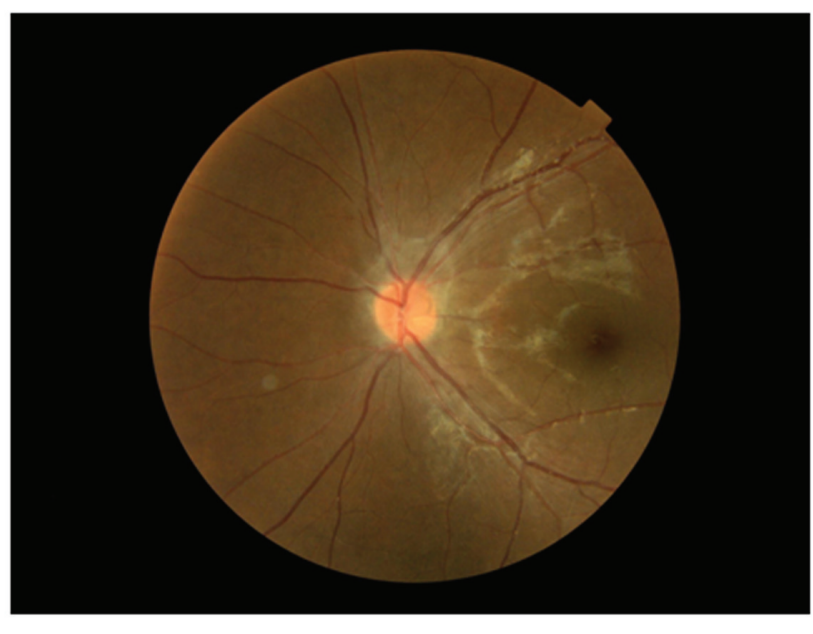

Figure 2 After the systemic antineoplastic treatments, A) visual field by Goldmann perimeter indicated no abnormalities. B) Fundus photograph showed a normal optic disc appearance. 


\section{Comments}

EBV is a DNA virus of the human herpes virus group, and infection does not always cause generalized or local symptoms. Primary infection with EBV leads to antibody formation followed, weeks or months later, by a serologic response to EBNA with formation of a virus carrier state that persists for life. ${ }^{2}$ Thus, even under normal ocular conditions, the DNA of EBV can be detected in the iris, ciliary body, retina, and choroid. ${ }^{3}$ Generally, patients with CAEBV manifest persistently elevated antibody titers of VCA and EA with low antibody titers of EBNA. ${ }^{4}$ In this case, high levels of anti-EBV antibody present at the onset and reduced levels present after the regression of clinical signs with chemotherapy indicated CAEBV.

Ocular involvement secondary to CAEBV is rare despite that genomic DNA of EBV can be detected in various ocular tissues, including the iris, ciliary body, retina, retinal pigment epithelium, and choroid. ${ }^{3}$ Although it has been reported in various ocular lesions, ${ }^{2,5}$ it is usually limited to a transient follicular conjunctivitis. Only two cases of unilateral optic swelling due to CAEBV have been reported, and in both cases, CAEBV with recurrent fever had been diagnosed before the onset of ocular symptoms. ${ }^{4}$ In our case, CAEBV was not diagnosed until the onset of ocular symptoms. Unilateral optic disc swelling without ocular inflammation was first observed, and subsequently ( 2 weeks later), the ocular inflammation of uveitis and retinal vasculitis with a slight fever was observed. The clinical course of this case indicates that the activation of EBV initially occurred in the optic neurons, which are the axons of retinal ganglion cells, and then spread to the posterior segments of the choroid and retina and to the anterior segment. Ophthalmologists should be aware that the immediate onset of a unilateral visual disturbance with optic disc swelling without any inflammation or intracranial disease may indicate CAEBV.

\section{Acknowledgment/disclosure}

The authors report no financial support or conflict of interests in this work.

\section{References}

1. Wong KW, D'Amico DJ, Hedges TR III, Soong HK, Schooley RT, Kenyon KR. Ocular involvement associated with chronic Epstein-Barr virus disease. Arch Ophthalmol. 1987;105:788-792.

2. Matoba AY. Ocular disease associated with Epstein-Barr virus infection. Surv Ophthalmol. 1990;35:145-150.

3. Kimura H, Morita M, Yabuta Y, et al. Quantitative analysis of Epstein-barr virus load by using a real-time PCR assay. J Clin Microbiol. 1999;37: 132-136.

4. Yamamoto $\mathrm{M}$, Ohga $\mathrm{S}$, Ohnishi $\mathrm{Y}$, Inomata $\mathrm{H}$. Optic disk vasculitis associated with chronic Epstein-Barr virus infection. Ophthalmologica. 2002;216:221-225.

5. Morishima N, Miyakawa S, Akazawa Y, Takagi S. A case of uveitis associated with chronic active Epstein-Barr virus infection. Ophthalmologica. 1996;210:186-188.
Clinical Ophthalmology

\section{Publish your work in this journal}

Clinical Ophthalmology is an international, peer-reviewed journal covering all subspecialties within ophthalmology. Key topics include: Optometry; Visual science; Pharmacology and drug therapy in eye diseases; Basic Sciences; Primary and Secondary eye care; Patient Safety and Quality of Care Improvements. This journal is indexed on

\section{Dovepress}

PubMed Central and CAS, and is the official journal of The Society of Clinical Ophthalmology (SCO). The manuscript management system is completely online and includes a very quick and fair peer-review system, which is all easy to use. Visit http://www.dovepress.com/ testimonials.php to read real quotes from published authors. 